\title{
Evaluation of Thyroid Function in Persons having Nodular Goiter without Thyroid Related Symptoms

\author{
${ }^{1}$ Md. Kabiruzzaman Shah, ${ }^{1}$ Nasrin Begum, ${ }^{1}$ Mosharruf Hossain, ${ }^{1}$ Parvez Ahmed, ${ }^{1}$ Monoarul Islam, ${ }^{\text {Shariful Islam }}$ \\ Chowdhuary and ${ }^{2}$ Mostofa Shamim Ahsan \\ ${ }^{1}$ Institute of Nuclear Medicine and Allied Sciences (INMAS), Rajshahi \\ 2 National Institute of Nuclear Medicine and Allied Sciences, Dhaka \\ E mail-shahkabirz@gmail.com
} \\ Correspondence Address : Dr. Md. Kabiruzzaman shah, Director, Institute of Nuclear Medicine and Allied Sciences, Rajshahi
}

\begin{abstract}
Objective: Objective of this study was to evaluate thyroid hormone level in nodular goiter patient without thyroid related symptoms and normal individual among the population of north-west part along the belt of river Padma. Patients and methods: It was a cross sectional study during the period of one year between July 2005 to June 2006. Total 200 samples were taken within 15 to 50 years age who attended in Institute of Nuclear Medicine \& Allied Sciences (INMAS) Rajshahi and OPD Rajshahi Medical college Hospital (RMCH). Diagnosed cases of hypothyroidism, hyperthyroidism, patients treated with radioiodine, pregnant and lactating lady, chronic illness, chronic kidney disease and known cardiac patients were not included in this study. An informed written consent was taken after counseling. Data were collected in predesigned data collection sheet and statistical analysis was performed.

Results: Total 100 patients of nodular goiter and 100 normal individual were enrolled for this study. About $37 \%$ of study groups were between the age of $20-30$ years and $31 \%$ in between 30-40 years of age. Male female ratio was 1:2.6. Cold nodular goiter was $75 \%$, multinodular goiter in $16 \%$ cases and partially cold nodular goiter in $9 \%$. The mean \pm SD of serum $\mathrm{T} 3$ was $1.89 \pm 0.61 \mathrm{nmol} / \mathrm{L}$ and $1.88+-0.44 \mathrm{nmol} / \mathrm{L}$ in study and control groups respectively. The mean \pm SD of serum $\mathrm{T} 4$ was $99.90 \pm$ $29.03 \mathrm{nmol} / \mathrm{L}$ and $122.93 \pm 25.31 \mathrm{nmol} / \mathrm{L}$ in study and control group and serum TSH was $1.42 \pm 1.07 \mathrm{mIU} / \mathrm{L}$ and $1.34 \pm-$ $0.54 \mathrm{mIU} / \mathrm{L}$ in study and control group respectively.

Conclusion: This study gave an impression in hormone status of nodular goiter patients in comparison to normal individual. Statistically no significance difference was seen in mean T3 and TSH value between study and control groups however significant difference was seen in mean serum $\mathrm{T} 4$ value $(\mathbf{p}<0.01)$.

Key words: T4 (Thyroxine), TSH- (Thyroid Stimulating Hormone), Nodular goiter, Radio-nuclide Scan, High Resolution Ultrasonography (HRUS), Radioimmunoassay (RIA) and Immuno-radiometric assay IRMA).
\end{abstract}

\section{INTRODUCTION}

Thyroid gland is the largest endocrine gland of the body. Thyroid disorder is one of the major public health problems in Bangladesh. It may be affected by pathological lesions of varied morphology, which can be divided into two types-those that show the diffuse pattern and those that produce nodules. Diffuse thyroid lesions are those that are mostly associated with non-neoplastic lesions affecting the gland. The nodular lesion consists of non-neoplastic nodules as well as benign and malignant tumors (1). The prevalence of thyroid nodules depends on the population studies. Solitary nodules belong to heterogeneous group of disorders that includes colloid nodules, adenomas, thyroiditis and simple cysts (2). Iodine is an essential raw material for thyroid hormone synthesis. Iodine deficiency related disorder e.g. simple diffuse goiter, non-toxic solitary nodule, simple multi-nodular goiter and toxic multinodular goiter comprised of $65.28 \%$ of all thyroid cases (3). Most of the cases thyroid nodules are asymptomatic, thyroid nodules are common and frequently benign. The prevalence of palpable thyroid nodules was found in $3 \%$ to $7 \%$ in North America; the prevalence is as high as $50 \%$ based on ultrasonography. The introduction of sensitive thyrotropin (TSH) assays, the widespread application of fine needle aspiration (FNA) biopsy, and the availability of high resolution US have substantially improved the management of thyroid nodules (4). The objective of this study was to determine the thyroid hormone status in clinically asymptomatic nodular goiter patients compare to biochemically euthyroid individual without any nodule among Bangladeshi population. 


\section{PATIENTS AND METHODS}

Total 200 people were obtained for this study, 100 were euthyroid nodular goiter patients and 100 normal individual. The study was carried out at the Institute of Nuclear Medicine and Allied Sciences and OPD of Rajshahi Medical College Hospital. Clinical history, physical examination and relevant investigations were done in all cases. Diagnosed case of hypothyroidism and hyperthyroidism, previous history radio-iodine therapy, pregnant lady and patient of chronic illness were not included in this study. High resolution ultra sonogram of thyroid gland was done by linear transducer of 7.5 to $9 \mathrm{MHz}$ of THOSIBA Just Vision 400 machine and SIMENS Ultrasound Systems machine. Radionuclide scan was performed by using Tc-99m and I-131 isotope to determine functional status of thyroid nodule and detected extra-thyroidal lesion by small field of view Gamma camera (SFOV) dedicated for thyroid. Thyroid hormone estimation was done by using RIA and IRMA method. All data of each patient were kept in a pre-designed data collection sheet. Statistical analysis was performed with the help of statistical package SPSS windows 12.0 version.

\section{RESULTS}

A total of 100 patients of nodular goiter and 100 control groups were enrolled for this study. The findings of the study obtained from data analysis are presented below.

Table1: Age distribution of nodular goiter patients $(n=100)$

\begin{tabular}{|l|r|r|}
\hline \multicolumn{1}{|c|}{ Age } & $\begin{array}{c}\text { Total Number of } \\
\text { Patient (N) }\end{array}$ & Percentage (\%) \\
\hline$<\mathbf{2 0}$ & 12 & $12 \%$ \\
$\mathbf{2 0 - 3 0}$ & 37 & $37 \%$ \\
$\mathbf{3 0 - 4 0}$ & 31 & $31 \%$ \\
$<\mathbf{4 0}$ & 20 & $20 \%$ \\
\hline \multicolumn{1}{|c|}{ Total } & 100 & $\mathbf{1 0 0} \%$ \\
\hline
\end{tabular}

Table 1 and 2 demonstrate that most of study population was between 20-30 years of age. Mean age of the patients was $30.02 \pm 9.742$ years of age. The mean age of the control groups was $31.08 \pm 8.8405$ years $48 \%$ of control groups were $20-30$ years of age.

Table 2: Age distribution of Control Group/normal population $(n=100)$

\begin{tabular}{|l|r|r|}
\hline Age & $\begin{array}{c}\text { Total Number of } \\
\text { Patient(N) }\end{array}$ & Percentage (\%) \\
\hline$<20$ & 9 & $9 \%$ \\
$20-30$ & 48 & $48 \%$ \\
$30-40$ & 27 & $27 \%$ \\
$<40$ & 16 & $16 \%$ \\
\hline \multicolumn{1}{|c|}{ Total } & 100 & $100 \%$ \\
\hline
\end{tabular}

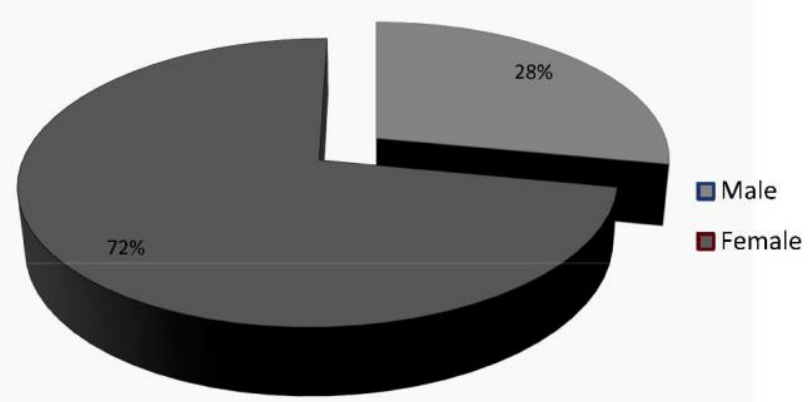

Figure 1: Sex distribution of patients showing male and female ratio 1:2.6.

Table 3: Findings of radio-nuclide scan in patients.

\begin{tabular}{|c|c|}
\hline Thyroid scan findings & $\begin{array}{c}\text { Total Number and } \\
\text { percentage N (\%) }\end{array}$ \\
\hline Partially Cold nodular goiter & 9 \\
Cold nodular goiter & $(9.0 \%)$ \\
Multi nodular goiter & $(75.0 \%)$ \\
& 16 \\
\hline Total & $(16.0 \%)$ \\
\hline
\end{tabular}

Table 3 shows thyroid scan findings, $75 \%$ were cold nodular goiter, multi-nodular goiters in $16 \%$ cases and partially cold nodular goiters in $9 \%$ cases.

\begin{tabular}{|c|c|}
\hline Ultrasonography & Total no and percentage N(\%) \\
\hline $\begin{array}{c}\text { Single nodule (Solitary nodular } \\
\text { goiter) }\end{array}$ & 84 \\
& $(84.0 \%)$ \\
$\begin{array}{c}\text { Multiple nodule (Multi nodular } \\
\text { goiter) }\end{array}$ & 16 \\
\hline Total & $(16.0 \%)$ \\
\hline
\end{tabular}

Majority of the patients were having single nodule in the thyroid gland it was $84 \%$ among the study groups. 
Table 5: Distribution of the patient according to character of nodules in ultrasonography

\begin{tabular}{|c|c|}
\hline $\begin{array}{c}\text { Ultrasonographic } \\
\text { appearance }\end{array}$ & $\begin{array}{c}\text { Total No and percentage } \\
\text { N }(\%)\end{array}$ \\
\hline Solid & 75 \\
& $(75.0 \%)$ \\
Cystic & 8 \\
Complex & $(8.0 \%)$ \\
& 17 \\
\hline Total & $(17.0 \%)$ \\
\hline
\end{tabular}

Among the patients $75 \%$ of the thyroid nodules were solid (both echogenic and hypoechoic), 17\% were complex and only $8 \%$ were Cystic.

The mean $\pm \mathrm{SD}$ of serum T3 was $1.89 \pm 0.61 \mathrm{nmol} / \mathrm{L}$ and $1.88 \pm 0.44 \mathrm{nmol} / \mathrm{L}$ in study and control groups. The mean \pm SD of serum T4 was $99.90 \pm 29.03$ $\mathrm{nmol} / \mathrm{L}$ and $122.93 \pm 25.31 \mathrm{nmol} / \mathrm{L}$ in study and control groups and mean \pm SD of serum TSH was $1.42 \pm 1.07 \mathrm{mIU} / \mathrm{L}$ and $1.34 \pm 0.54 \mathrm{mIU} / \mathrm{L}$ in study and control groups respectively.

Table 6: Range, mean \& SD of T3, T4 and TSH distribution in study and control groups.

\begin{tabular}{|c|c|c|c|c|c|}
\hline Hormone & Group & Range & Mean & SD & P(Value) \\
\hline $\mathrm{T}_{3} \mathrm{nmol} / \mathrm{L}$ & $\begin{array}{l}\text { Control } \\
\text { group } \\
\text { Study } \\
\text { group }\end{array}$ & $\begin{array}{l}1.24- \\
3.21 \\
1.23- \\
3.51\end{array}$ & $\begin{array}{r}1.88 \\
1.89\end{array}$ & 0.44 & 0.641 \\
\hline $\mathrm{T}_{4} \mathrm{nmol} / \mathrm{L}$ & $\begin{array}{l}\text { Control } \\
\text { group } \\
\text { Study } \\
\text { group }\end{array}$ & $\begin{array}{l}76.00- \\
175.50 \\
55.01- \\
173.51\end{array}$ & $\begin{array}{l}122.93 \\
99.90\end{array}$ & $\begin{array}{l}25.31 \\
29.03\end{array}$ & $<0.01 * *$ \\
\hline $\begin{array}{l}\text { TSH } \\
\mathrm{mIU} / \mathrm{L}\end{array}$ & $\begin{array}{l}\text { Control } \\
\text { group } \\
\text { Study } \\
\text { group }\end{array}$ & $\begin{array}{l}0.44- \\
3.11 \\
0.30- \\
6.16\end{array}$ & $\begin{array}{l}1.34 \\
1.42\end{array}$ & $\begin{array}{l}0.54 \\
1.07\end{array}$ & 0.783 \\
\hline
\end{tabular}

** statistically significant difference

Ranges, Mean, SD of Serum T3, T4 and TSH in Control \& Study Groups are shown in Table 6. Statistically no significant difference was seen in mean serum T3 and
TSH between study and control groups. But significant difference was seen in mean serum $\mathrm{T} 4(\mathrm{p}<0.01)$.

\section{DISCUSSION}

The aim of the study was to determine any difference between thyroid hormone status of clinically asymptomatic nodular goiter patients and normal individual. Patients with nodular goiter with no evidence of thyroid illness were selected as case and euthyroid person having no nodule as control. The mean age of the patient was $33.02 \pm 9.472$ years and control group was $31.08 \pm 8.805$ years. In control group, $48 \%$ were within $20-30$ years age group and $37 \%$ of study population were within the age group of 20-30 years. One study showed age adjusted range of T3 is $1.23-3.10 \mathrm{nmol} / \mathrm{L}$ above 15 years of age. T4 is $58.0-$ $154.5 \mathrm{nmol} / \mathrm{l}$ above 12 years of age and TSH is 0.6$4.8 \mathrm{mIU} / \mathrm{L}$ (5). In current study, no statistical difference was seen in mean serum T3, T4 \& TSH levels of nodular goiter patients and normal individual in different age groups as well. Thyroid nodules are common and frequently benign. Thyroid ultrasonogram should not be performed as a screening test, however all patients of thyroid nodule should undergo ultrasound examination. In this study, ultrasound was performed in all persons of study group. In geographic regions with iodine deficiency, thyroid scintigraphy is still used as a part of the evaluation of the patients with thyroid nodules (6). It provides useful information about functional characteristic of thyroid nodules. The patients in these regions serum TSH may remain unsuppressed even autonomy is present as because; low synthesis rate of thyroid hormones by iodine depleted thyroid gland (7).

Measurement of serum TSH concentration is the most useful single laboratory test in the initial evaluation of thyroid nodules (8). If TSH levels are within normal range, the measurement of T3, T4/FT3, and FT4 hormones level add no further relevant information. In high serum TSH level cases, estimation of FT3/T3 and FT4 / T4 and TPOAb are done to evaluate 
hypothyroidism. Serum TSH level low -Test FT3/T3 and FT4 / T4 to evaluate hyperthyroidism (9). In current study, the mean value of serum TSH in control group and case were $1.34 \mathrm{mIU} / \mathrm{L}$ and $1.42 \mathrm{mIU} / \mathrm{L}$ (no statistical significance difference between the control and cases). Mean T4 in study and control group were $122.93 \mathrm{nmol} / \mathrm{L}$ and $99.90 \mathrm{nmol} / \mathrm{L}$ respectively, though there is significant difference of T4 levels between study and control groups, however, did not reflect any problem, value was within normal range. No statistical significance difference present in mean value of T3 in study and control groups.

This is a small scale study; however this provides a guideline for the diagnosis and management of thyroid nodules which support the guideline of American Association of Clinical Endocrinologist (AACE) task force of thyroid nodules.

\section{CONCLUSION}

Although the value of T3, T4 and TSH hormones may appear within the standard normal range in nodular goitrous patients, difference between values of $\mathrm{T} 4$ hormone among those groups and normal population may exist and even statistically significant which represent the ongoing damaging process of thyroid hormone storage and distribution within those nodular thyroid glands. Because majority of the thyroid hormones is stored within the thyroid gland as T4 hormone which, in turn, is converted into the active $\mathrm{T} 3$ hormone at the site of peripheral body cells during metabolic reactions. This may be concluded that asymptomatic patients with thyroid nodules need subsequent follow up for assessment of thyroid functional status to start early management.

\section{REFERENCES}

1. Livosi VA Pathology of thyroid disease. In: SA Falk., ed. Thyroid disease, Philadelphia PA, Lipincott-Raven publishers, 1997: 65-105.

2. Fey MF, Peter H J, and Hinds $\mathrm{H} L$ et al.Clonal Analysis of Human tumours with M 27 Beta, highly Informative X chromosomal Probe, J Clin Invest, 1992; 89: 1438-44.

3. Alam MN, Haq SA, Ansari MAJ, Karim MA, Das K K, Baral P K, Zia-ur-Rahman ANM, Nisa L, Hasan M, Afroz S, Yasmin S, Haque M M, Spectrum of Thyroid Disorder in IPGMR, Bangladesh J Med 1995; 6:523-58.

4. Gharib H, E Papini, R Valcavi, Thyroid Nodule Guideline, Endocrine Practice 2006; 1(12): 70.

5. Sills I N, Horlick MNB, Rapaport R, Inappropriate Suppression of Thyrotropin During Medical Treatment of Graves' Disease in Childhood, J Pediatr 1992; 163: 262-63.

6. Bonnema SJ, Bennedback FN, Hegedus L. Danish Endocrinologist Examination and Treatment Of Non-toxic Multinodular Goiter : a Questionnaire Study [article in Danish]. Ugeskr Laeger, 2001;163:1265-69

7. Helleahinrichs E. Ultrasonography vs Scintigraphic Measurement of Thyroid Volume in Patient of Thyroid Nodules Referred for I 131 Therapy, Nucl Med Commun 1998;19:341-46

8. Meller A, LoyTJ, Herle A J. Diagnosis and Management of Solitary Thyroid Nodules. Br J Surg 2002; 78: 90-93.

9. Baloch Z, Carayon P, Contee-Devolse B et al. Guidelines Committee, National Academy of Clinical Bio-chemistry, Laboratory Medicine Practice Guidelines : Laboratory Support for the Diagnosis and Monitoring of Thyroid Disease . Thyroid 2003; 13: 3-126. 